\title{
Effectiveness of Life Skill Trainings in Ego Power, Temperament, and Suicidal Thoughts among Girls and Boys Attempting to Commit Suicide in Ilam Province, Iran
}

\author{
Shahryar Mehrdadi $^{1}$ iD , Fariba Hassani ${ }^{1}$ iD , Farnaz Keshavarzi', Mahdeh Salehi ${ }^{1}$, Mozhgan Sepah \\ Mansour $^{1}$ \\ ${ }^{1}$ Dept of General Psychology, Islamic Azad University, Central Tehran Branch, Tehran, Iran
}

Article Info A B S T R A C T

Article type:

Research article

\section{Article History:}

Received: 09 February 2021

Revised: 14 April 2021

Accepted: 19 June 2021

\section{* Correspondence to:}

Fariba Hassani

Dept of General Psychology, Islamic Azad University, Central

Tehran Branch, Tehran, Iran

Email: hassani.fariba@gmail.com
Introduction: Suicide is caused by the interaction of many factors; however, most suicides are preventable. If suicide does not lead to death, there is concern that the behavior may be repeated. Teaching life skills based on participatory and practical learning is very effective in increasing health and early prevention of problems, as well as helping adolescents to learn positive behaviors and maintain their mental health. This study aimed to compare the effectiveness of life skill training in ego power, temperament, and suicidal thoughts among the girls and boys who attempted to commit suicide in Ilam province, Iran.

Material \& Methods: This semi-experimental study was conducted based on a pretest-posttest design with control and follow-up groups. The statistical population of the research included all boys and girls aged 18 to $24(n=212)$ in Ilam province who for the first time over the past six months in 2018-2019 committed suicide and were referred to the medical centers of this province. In total, 80 cases were purposefully selected as an accessible sample and were matched and assigned into (based on education status) the experimental (20 girls and 20 boys) and control groups ( 20 girls and 20 boys). The data were collected using the temperament scale, ego scale, and suicidal thought scale. The data were analyzed through variance analysis with frequent measurements. (Ethic code:10120705972003)

Findings: The results of analysis of variance showed a significant difference in prepost life skill training test among girls and boys who attempted to commit suicide in Ilam province in the experimental, control, and follow-up groups in terms of the level of temperament, ego power, and suicidal thoughts. Similarly, multivariate analysis of variance showed that life skill training in group type and test status had an effect on temperament and its dimensions, ego power, and suicidal thoughts of boys and girls who attempted to commit suicide in Ilam province.

Discussion \& Conclusion: According to the findings it can be concluded that life skills training has been effective in ego power, temperament, and suicidal thoughts of girls and boys who attempted suicide both in the post-test and follow-up stages.

Keywords: Ego power, Life skills, Suicidal thoughts, Temperament

\footnotetext{
$>$ How to cite this paper
}

Mehrdadi Sh, Hassani F, Keshavarzi Arshadi F, Salehi M, Sepah Mansour M. Effectiveness of Life Skill Trainings in Ego Power, Temperament, and Suicidal Thoughts among Girls and Boys Attempting to Commit Suicide in Ilam Province, Iran. Journal of Ilam University of Medical Sciences. November 2021;29(4): 46-59. 


\section{اثربخشى آموزش مهارتهاى زندكى بر قدرت ايكو، خلقوخو و افكار خودكشى در دختران و اقو

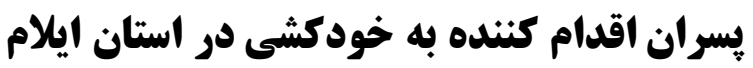

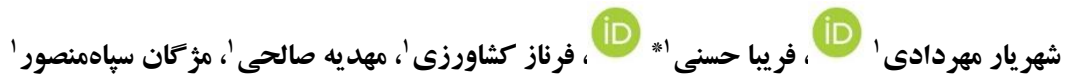

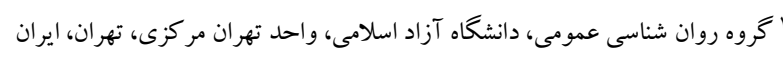

\section{جـيده}

مقدمه: خود كشى درنتيجهُ تعامل عو امل متعدد بهوجود مى آيد. بالين حال، بيشتر خود كشىها قابل ييشگيرى هستند. اخر اقدام

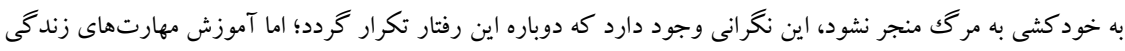

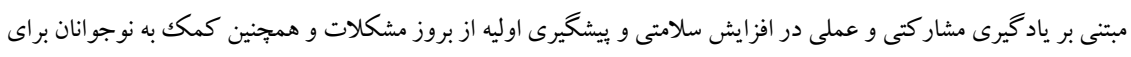

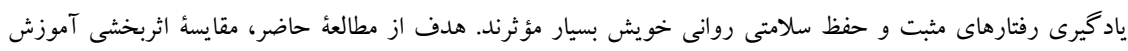
مهارت هاى زندكى بر قدرت ايكو، خلقوخو و افكار خود كشى در ميان دختران و يسران اقدام كننده به خود كشى در استان ايلام است.

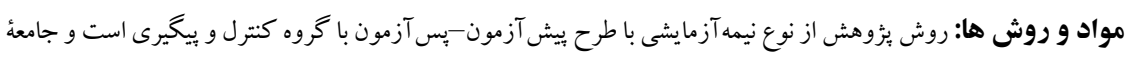

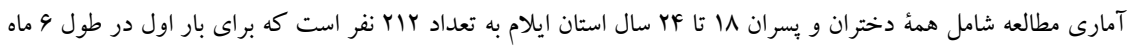

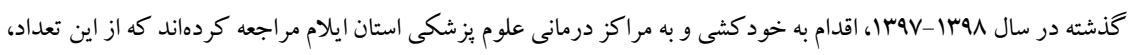
بر اساس ملاككهاى ورود، تعداد •منفر بهصورت نمونه در دسترس انتخاب شدند و بهصورت همتاسازى (بر اساس تحصيلات)

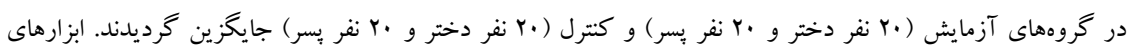
استفادهده شامل مقياس خلقوخو، مقياس قدرت ايخو و مقياس افكار خودكشى است. دادهها از طريق آزمون تحليل واريانس با اندازهيرىهاى مكرر تجزيلو تحليل شدند. يافتها: در نتايج تحليل واريانس مشاهده گرديد ميزان خلقوخو، قدرت ايخو و افكار خود كشى در ميان دختران و يسران

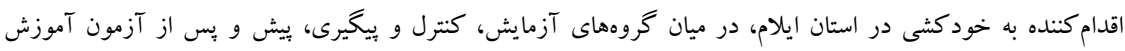
مهارت هاى زندگى تفاوت معنادارى وجود دارد. به همين ترتيب، تحليل واريانس جندمتغيره نشان داد كه آموزش مهارتهات

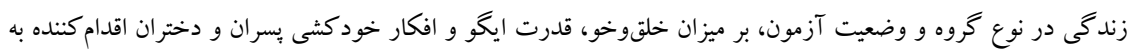

$$
\text { خود كشى در استان ايلام تأثير خذار بوده است. }
$$

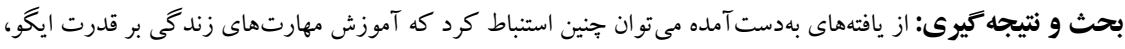

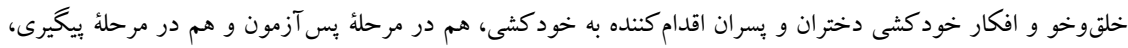

$$
\text { اثربخش بوده است. }
$$

\section{JIMUS}


داشته است، بهطورى كه ميزان بروز خود كشى از Y/ نفر در هر صد هزار نفر در سال 99 هزار نفر در سال هیمارسيده است. همين آمارها در سال هاى بعدى نشان مىدهد كه مثلاً نرخ خود كشى در سال צNM

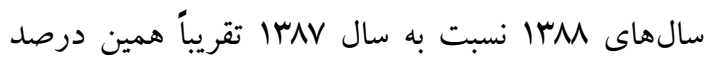
افز ايش داشته است (r).

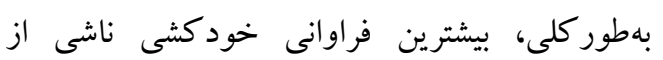

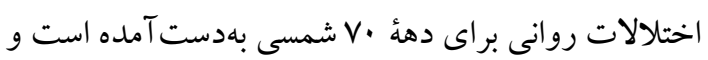
با توجه به اينكه طى هشت سال دفاع مقدس در برابر كشور

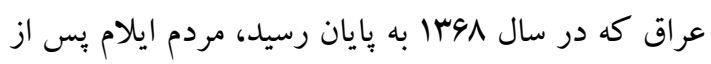

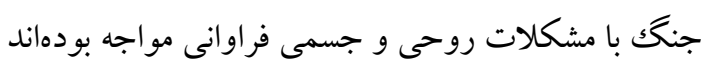

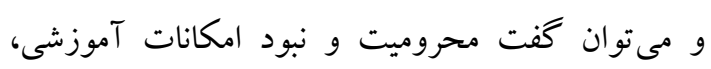

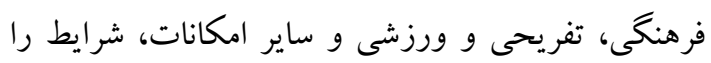
براى قشر نوجوان و جوان سخت تر و در برخى موارد، زمينه آسيب هاى اجتماعى را نيز فراهم كرده است. از نظر ميزان

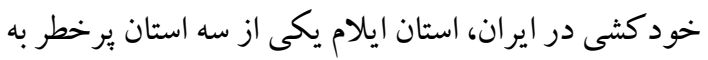

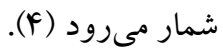
برخى مطالعات افكار خود كشى را عامل مؤثر در اقدام به خودكشى مىدانند. افكار خودكشى با واكنشهاى

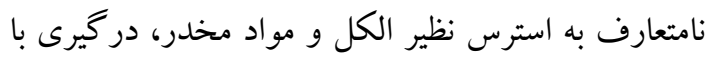

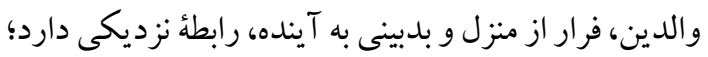

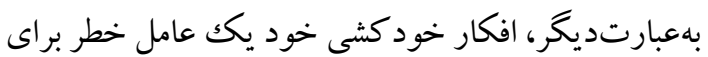
خود كشى محسوب مى شود. يافتهاى يزوهش هاى مختلف نشان مىدهد كه موارد ناموفق خودكشى بيشتر از موارد موفق، با اختلالات روانى و روانشناختى افراد در ارتباط

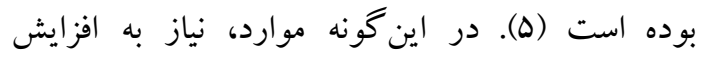

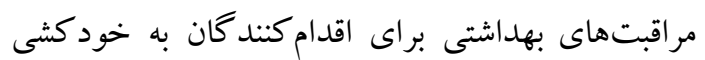
بيشازييش ديده مى شود و بدين منظور، بايستى اقدامات

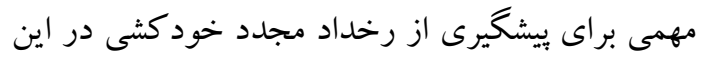

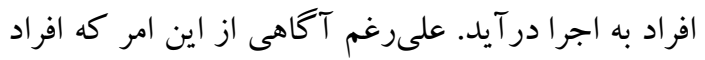

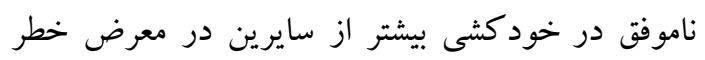

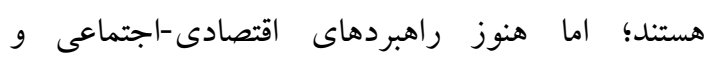

امروزه، خودكشى از جدىترين و يرخطرترين آسيبهاى اجتماعى است كه شاهد روند روبهرشد آن در

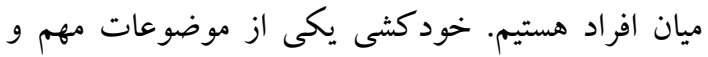
داراى اولويت در بخش سلامت بهشمار مى آيد و معلول عوامل متعددى است كه در جوامع مختلف متفاوت است.

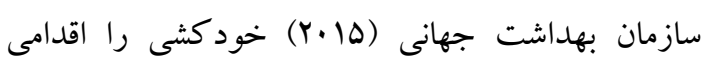
آكاهانه و ارادى تعريف كرده است كه در آن، فرد بان

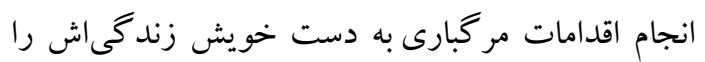

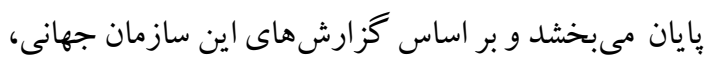

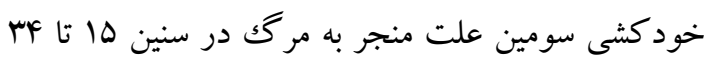

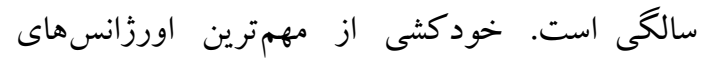
روانيزشكى محسوب و اهميت آن روزبهروز بيشتر مى گردد (1). نرخ خودكشى در جهان rان-11ا نفر در هر يككصد هزار نفر است. اين در حالى است كه نرخ اقدام به درد درد خود كشى در ايران در سال اجها، ه.4 نفر در هر يككصد هزار نفر است. نرخ خودكشى مردان و زنان در ايران به ترتيب r.r و r.1 است و استان ايلام بحرانىترين استان

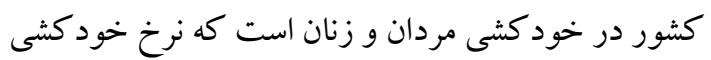

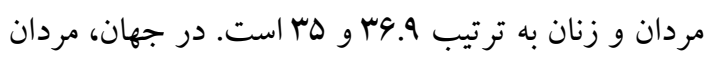

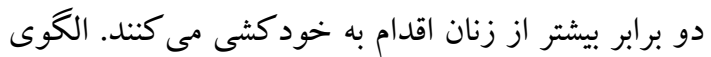

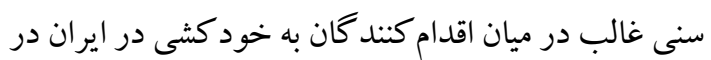

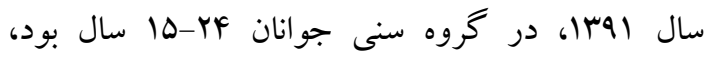

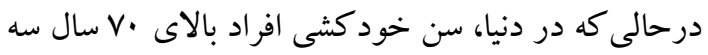

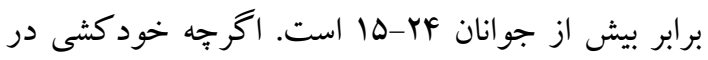

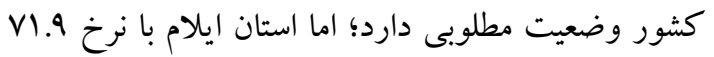
درصد، شانزده برابر نرخ كشورى است و عملاً بالاترين نرخ خود كشى در جهان را دارد (Y).

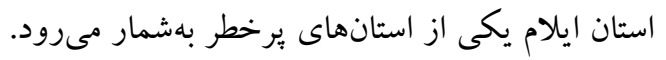

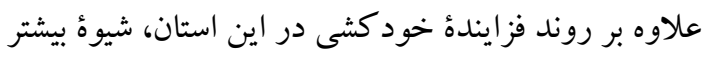

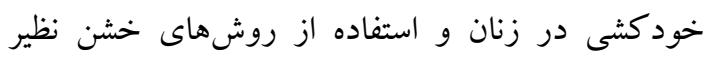

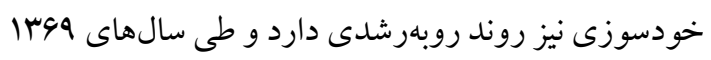

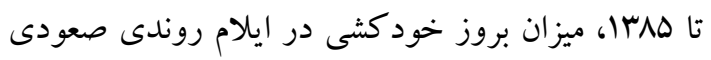


اقدام مىروند. اقدام به خودكشى رابطهُ نزديكى با خود كشى كامل دارد؛ مثلاً ·. تا · V درصد كسانى كه خود را كشتهاند، دست كم يككبار در گذشته به خود كشى اقدام كرده بودند و r تا •V درصد كسانى كه اقدام به خود كشى مى كنند، عاقبت در اثر آن جان خود را از دست مىدهند؛

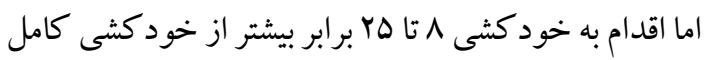
رخ مىدهد (A). اخر اقدام به خودكشى افراد منجر به مرگك نشود، اين نخر انى وجود دارد كه دوباره اين رفتار تكرار كردد. شواهد همه گيرشناختى نشان مى دهد كه افراد افسردهاى كه بهطور مكرر افكار خودكشى فعال دارند و بيشتر نيز اقدام به خود كشى كردهاند، بيشتر در معرض خود كشى موفق قرار

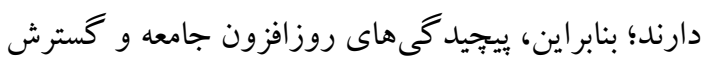
روابط اجتماعى، آمادهازى افراد بهويزه نسل جوان با موقعيتهاى دشوار و مجهز كردن آنان به راهبردهاى مقابلهاى، امرى ضرورى بهنظر مىرسد. يكى از مهم ترين راهبردهاى مقابلهاى نوجوانان و جوانان، داشتن مهارت هاى زندگى است. آموزش مهارتهاى زندگى مبتى بر ياد گيرى مشاركتى و عملى است و اين گونه فعاليتها در افزايش سلامتى و بيشخيرى اوليه از بروز مشكلات و همجنين كمكك به نوجوانان براى ياد كيرى رفتارهاى مثبت و حفظ سلامت روانى خويش بسيار مؤثرند (9)؛ بنابر اين، افزايش دسترسى گروههاى در معرض خطر اقدام به خودكشى، به خدمات بهداشت روانى و خدمات روانشناختى با ايجاد آموزش مهارتهاى زندىى، مسئلهاى است كه در اين يزٔوهش به آن يرداخته خواهد شد؛ لذا خلأ علمى و مسئلهاى كه يزوهشكر را به بررسى آنى اثربخشى آموزش مهارت هاى زندگى بر خلقوخو، قدرت ايخً و افكار خود كشى افر اد اقدام كننده به خود كشى استان ايلام واداشت، اين است كه برنامهُ آموزش مهارتهاى زندگى جِه تأثير و رابطهاى بر خلقوخو، قدرت ايخو و و افكار خودكشى در دختران و يسران اقدامكنده به خود كشى در استان ايلام خواهد داشت؟ و يرسش اصلى

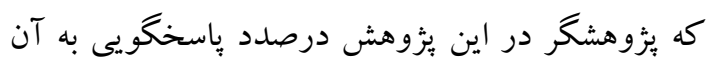

مداخلهاى موفقى براى بيشخيرى از آنها صورت نمىيذيرد.

بسيارى از محققان اقدام به خود كشى را با اختلالات خلقى مر تبط مى دانند، كه با بعضى از ويز كى هاى شخصيتى مرتبط هستند و به علت اينكه ويز گیى هاى شخصيت نسبتاً ثابتاند، مىتواند در بيشبينى احتمال افكار خود كشى و اقدام به خودكشى فرد اهميت داشته باشند؛ بنابراين، يرداختن به مقوله شخصيت و بررسى ابعاد آن مى تواند در ييشخيرى از اقدام به خود كشى نقش مهمى داشته باشد. از نظر كلانينجر، هريك از اين جنبههاى شخصيت با يكديخر در تعامل هستند و بر ايجاد اختلالات رفتارى و هيجانى تأثير مى خذارند (4) (4) قدرت ايگو يكى ديخر از متغيرهايى است كه تحت تأثير آموزش مهارتهاى زندگى قرار دارد و بر افكار

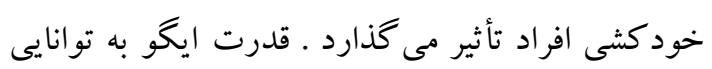
فرد براى برخورد مؤثر با خواستههاى رقابت آميز، موقعيتهاى توانفرسا و براى عملكرد مؤثر بهرغم خواستها و توقعات اين نيروهاى متعارض به كار مىرود. ايخًو وظيفهُ مديريت دستخاه روانى را بر عهده دارد. همة مشكلات روانى هنگامى ظاهر مىشوند كه ايخو نتواند به مسئوليتهايش عمل كند. بنابراين، وجود يك ايكو قدرتمند باعث مىشود كه افراد از خود نشانهاى آسيب روانى كمترى نشان دهند و در برابر تنش ناشى از شرايط فشارزاى زندگى تحمل و ظرفيت كافى داشته باشند و درنتيجه، اقدام به خود كشى بهطور

$$
\text { جشمخيرى كاهش يابد (V) }
$$

خود كشى درنتيجه تعامل عو امل متعدد زيستشناختى، زنتيك، روانشناختى، اجتماعى، فرهنگى و و محيطى

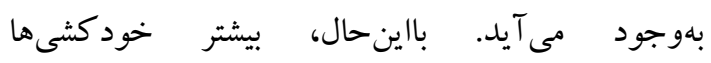
قابليشگيرى هستند. كذر از فكر خود كشى به نقشه كشيدن در بس درصد افراد (داراى فكر خود كشى) و كذر فئر از نقشَ خود كشى به اقدام در VY درصد افراد (داراى نقشه خود كشى) صورت مى گيرد. درنتيجه، YF درصد افرادى كه فكر خود كشى را كزارش مى كنند، درنهايت به سوى 
بهصورت صحيح و غلط پِاسخ مىدهد. در اين بزروهش،

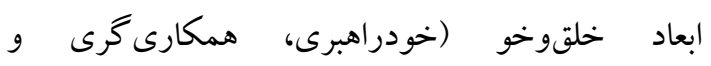
خودفراترنخرى) اندازهيرى مىشود كه مشتمل بر 94 يرسش است. كاويانى و حقشناس (IrAF) ضريب قابليت

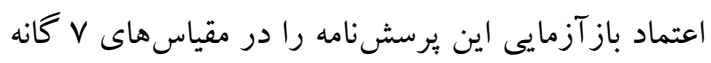

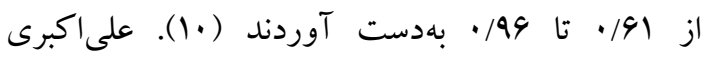

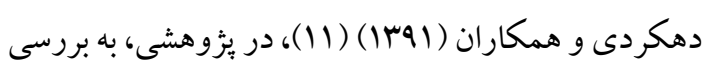

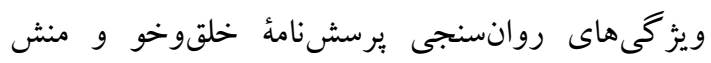
كلانينجر در ميان نوجوانان شهرستان شهريار برداختند و

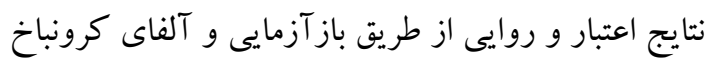
به ترتيب ضرايب هA/ • و rA/· بهدست آمد. براى محاسبة روايى نيز از شاخصهاى روايى همخرا و روايى سازه

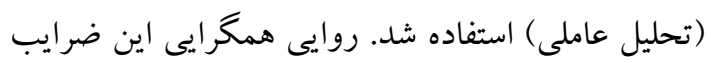

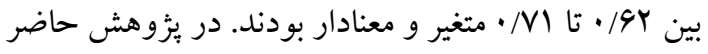

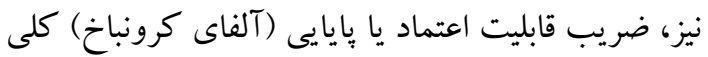
يرسشنامة خلقوخو (كلانينجر و همكاران) NF/ و و

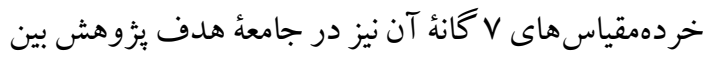
(99/9 • تا س • • بهدست آمد.

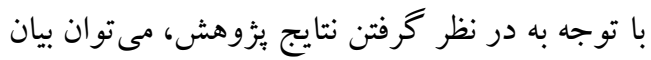

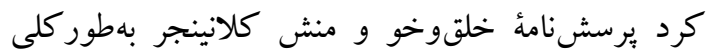

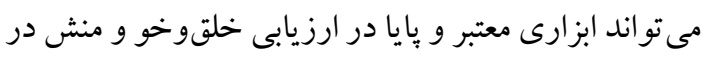
نوجوانان ايرانى باشد. در اين يزوهش، تنها ابعاد خلقوخو (خودراهبرى، همكارى، خودفراترنخرى) بررسى مى شود.

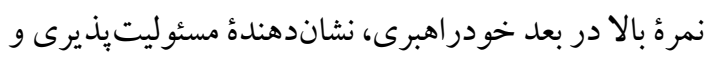
هدفمندى در زندگى است و نمرة بايين در آن نشاندهندة ضعف، خستخى، بىهدفى، درماندگى و بـىمسئوليتى

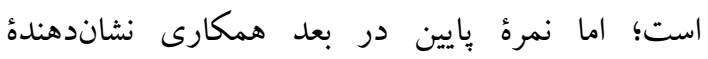

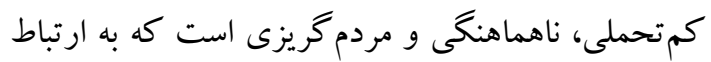
بينفردى ضعيف و حمايت اجتماعى هايين منجر مى شود و

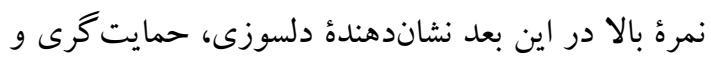
قدرت تحمل است. درنهايت، در بعد خودفراروى، نمرة

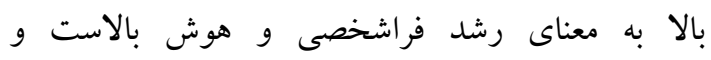

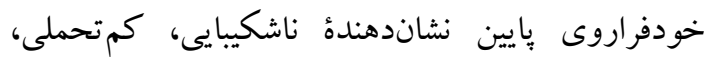

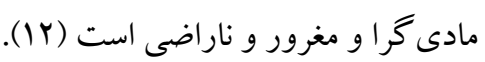

است، اين است: (آيا برنامةُ آموزش مهارتهاى زندگى بر

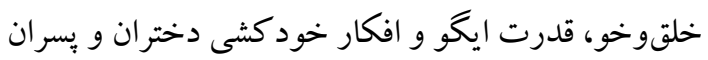

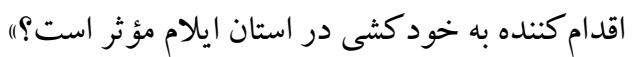

مواد و روش ها

روش يُزوهش حاضر از نوع نيمهآزمايشى و طرح

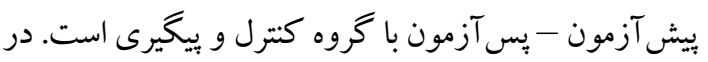

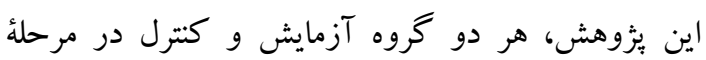

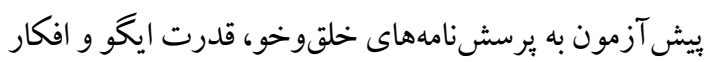

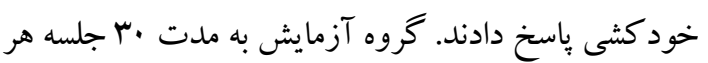

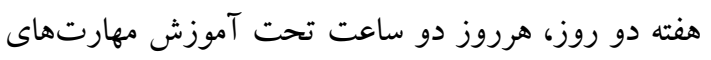
زندگى قرار گرفتند. گروه كنترل آموزشى دريافت نمى كنند.

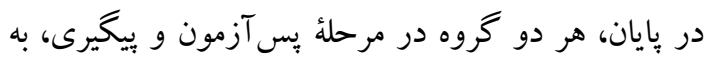

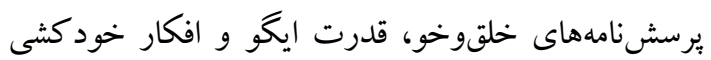

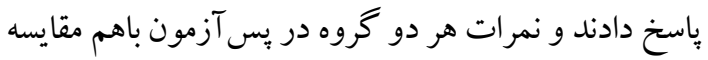

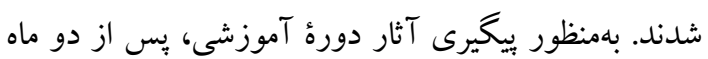

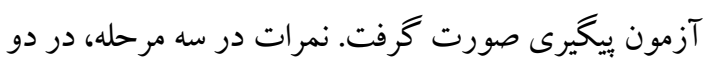
گروه آزمايش و كنترل با يكديخر مقايسه گرديدند. جامعة آمارى يُزوهش شامل همة دختران و بِران

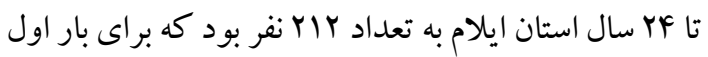

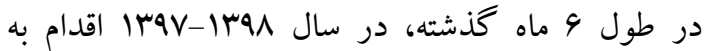
خودكشى و به مراكز درمانى علوم يزشكى استان ايلام مر اجعه كردهاند كه از اين تعداد بر اساس ملاككهاى ورودد، تعداد •م نفر با روش نمونه گيرى در دسترس (با روش مصاحبه بهصورت اتفاقى تا تكميل نمونه يُزوهشى) انتخاب شدند و بهصورت همتاسازى (بر اساس تحصيلات) در كروههاى آزمايش (·r نفر دختر و •r نفر هـر ) و كنترل

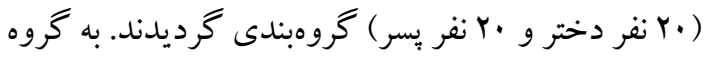
آزمايش در محل ساختمان سازمان ملى جوانان استاندارى

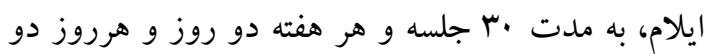
ساعت، آموزش مهارت هاى زندگى ارائه شد.

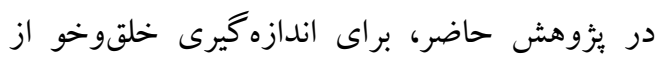

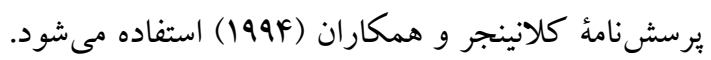

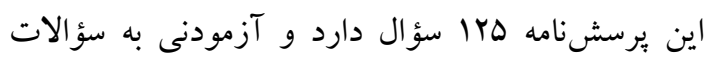


نشان داد كه همؤ سؤالات با نمرة كل همبستخى معنادارى

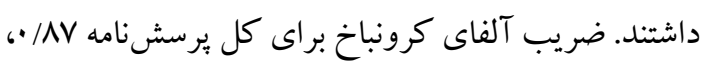

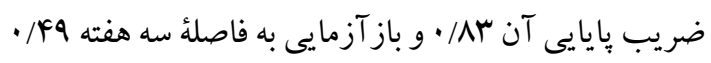

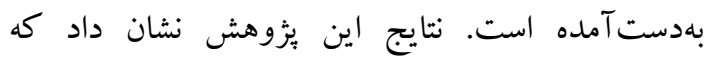

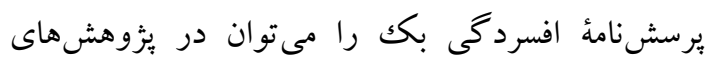

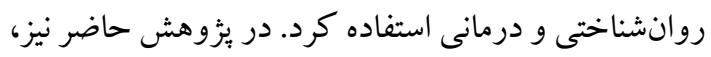

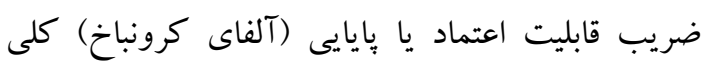

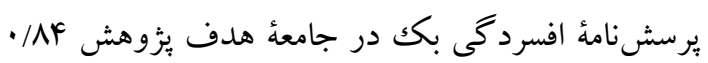

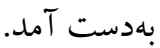

\section{يافته ها}

همانطور كه در جدول شمارهُ امشاهده مى شود، آثار

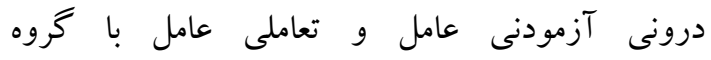

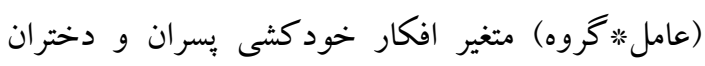
اقدامكنده به خود كشى در استان ايلام، در هر سه آزمون

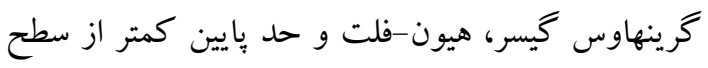
معنادارى ه•/ است؛ بنابراين نتيجه مىشود كه نمرات

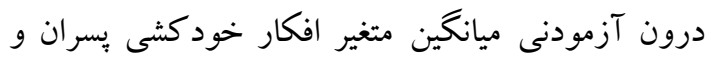
دختران اقدام كننده به خودكشى در استان ايلام، در ميان كروهها و وضعيتهاى آزمون، متفاوت است؛ همجِنين ميزان اثر درون آزمودنى مجذور اتاى جزئى عامل و عامل

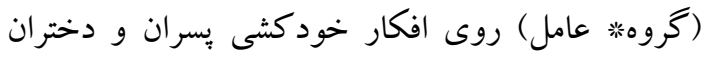

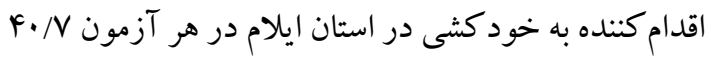
درصد است كه مقدار بالايى است. از سويى، همانطور كه

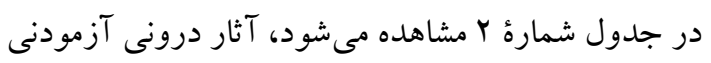
اثر تعاملى عامل با جنسيت (عامل جات جنسيت) و اثر تعاملى

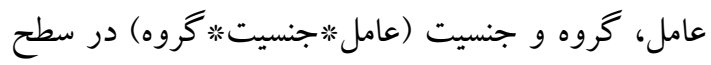
خطاى هـ/ معنادار نشده است؛ زيرا خطاى آزمونهاى

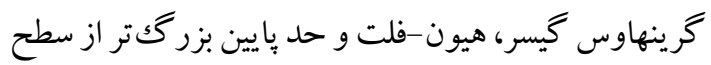

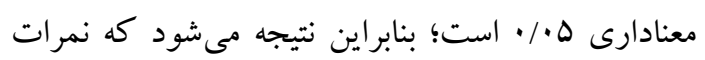

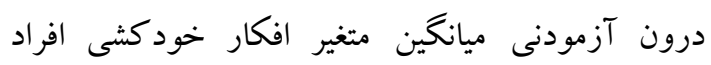
اقدام كننده به خود كشى استان در ايلام، برحسب جنسيت آنسيت

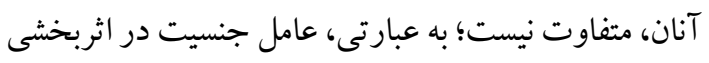

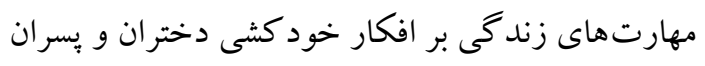

براى ارزيابى ساز كارى كلى روانى فرد از مقياس قدرت

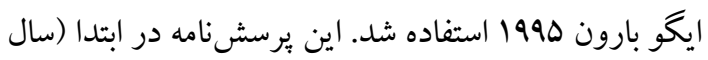

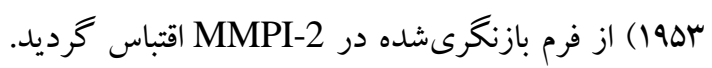

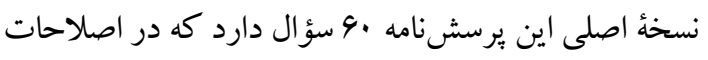
انجامشده در نسخة ترجمهشده به فارسى، اين مقياس حاوى

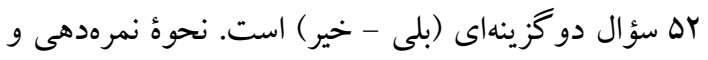

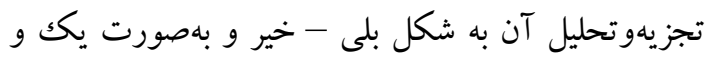

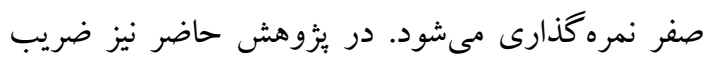

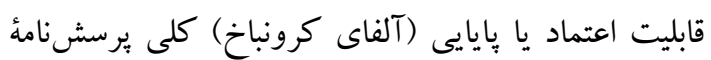

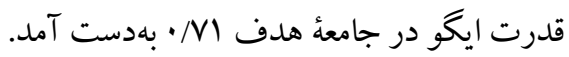

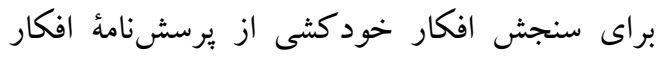

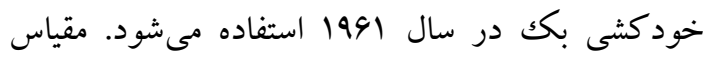
سنجش افكار خودكشى بكى، يكك ابزار خودكشى 19 سؤالى است. اين :برسشنامه بهمنظور آشكارسازى و و

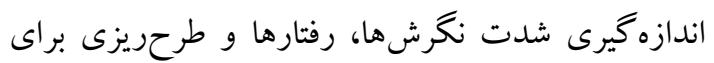

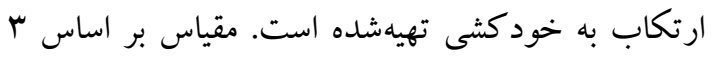

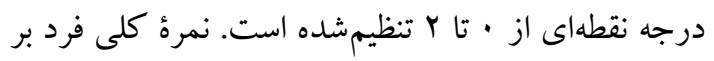

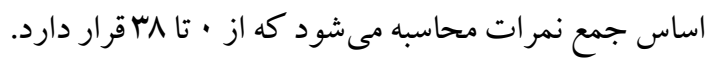

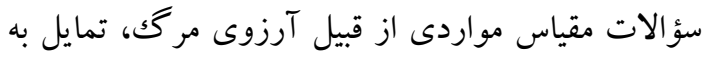
خود كشى بهصورت فعال و نافعال، مدت و فراوانى افكار خودكشى، احساس كنترل بر خود، عوامل بازدارندة

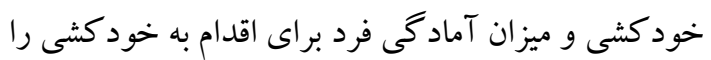

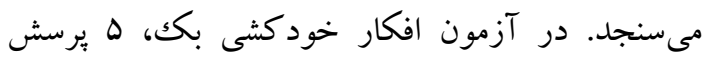

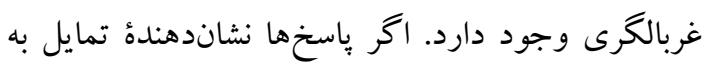
خودكشى فعال يا نافعال باشد، آزمودنى بايستى أل أسؤال

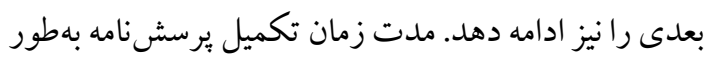
متوسط • ا دقيقه است. در مقياس بكك، براى شناسايى ميزان

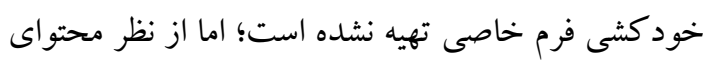
سؤالات مى توان خطر خود كشى را به اين شكل تعيين كرد:

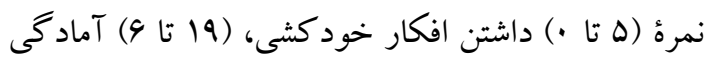

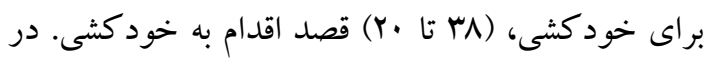

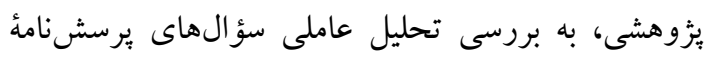

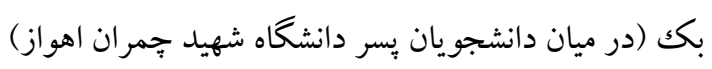

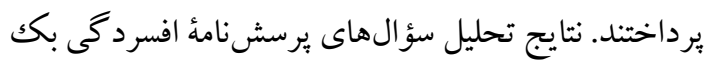


جدول ا. نتايج آثار درون آزمودنى حاصل از تحليل واريانس با اندازهيرى مكرر روى ميانكين افكار خودكشى بسر ان و دختران اقدامكنده به خود كشى در استان ايلام

\begin{tabular}{|c|c|c|c|c|c|c|c|}
\hline تفاوت ميان & معنادارى سطح & خطاى & خانغين & آزادى درجه & اندازه مكرى & آزمون & اثر \\
\hline$F \cdot / V$ & $<\cdot / \cdot \cdot 1$ & $\Delta Y / Y Y T$ & rG9/ODF & r & $\Delta \Pi \pi / 1 \cdot \Lambda$ & فرض اسفيرسيتى & \multirow{8}{*}{ 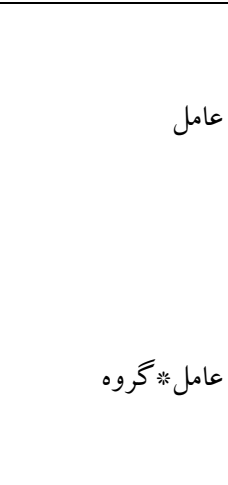 } \\
\hline$r \cdot / V$ & $<\cdot / \cdot \cdot 1$ & $\Delta r / Y Y T$ & MFN/YGA & $1 / \Delta r \mid$ & $\Delta r / / \cdot \lambda$ & خرينهاوس گيسر & \\
\hline$r \cdot N$ & $<\cdot / \cdot \cdot 1$ & $\Delta r / Y Y T$ & rYq/QVF & $1 / 911$ & $\Delta r / 1 \cdot \Lambda$ & هيون- فلت & \\
\hline$r \cdot / V$ & $<\cdot / \cdot \cdot 1$ & $\Delta Y / Y Y T$ & $\Delta \Gamma / 1 \cdot \lambda$ & $1 / \cdots$ & $\Delta r / / \cdot \Lambda$ & حد هايين & \\
\hline$r \cdot / V$ & $<\cdot / \cdot .1$ & $\Delta r / \cdot V G$ & $r 9 \Delta / A \cdot r$ & r & $\Delta M / / 9 \cdot 1$ & فرض اسفيرسيتى & \\
\hline$r \cdot / V$ & $<\cdot / \cdot .1$ & $\Delta r / \cdot V q$ & TFV/TAQ & $1 /\left.\Delta\right|_{1}$ & $\Delta M I / 9 \cdot \Lambda$ & گرينهاوس گيسر & \\
\hline$r \cdot / V$ & $<\cdot / \cdot \cdot 1$ & $\Delta r / \cdot V q$ & RYN/GFG & $1 / 911$ & $\Delta r \mid / 9 \cdot \Lambda$ & هيون-فلت & \\
\hline$r \cdot / V$ & $<\cdot / \cdot \cdot 1$ & $\Delta r / \cdot V q$ & $\Delta r / / 9 \cdot 1$ & $1 / \cdots$ & $\Delta M / / 9 \cdot 1$ & حد بايين & \\
\hline$\cdots /$ &.$/ 994$ &.$/ .4$ &.$/ \cdot r^{\prime}$ & r & $\cdot / \cdot \Delta \wedge$ & فرض اسفيرسيتى & \multirow{4}{*}{ عامل *جنسيت } \\
\hline$\cdots /$ &.$/ 94 r$ &.$/ .4$ & . & 1/Or| & $.1 . \Delta \wedge$ & گرينهاوس گيسر & \\
\hline$\cdots /$ & $\cdot / 919$ & $\cdot / . .4$ & .1 .49 & $1 / 911$ &.$/ . \Delta \wedge$ & هيون-فلت & \\
\hline$\cdots /$ & - /QF. & $\cdot / . \cdot 4$ & $\cdot 1 \cdot \Delta \Lambda$ & $1 / \cdots$ &.$/ \cdot \Delta \Lambda$ & حد بايين & \\
\hline$\cdots /$ & $\cdot / 994$ & $\cdot / . .4$ & .1 .79 & r &.$/ \cdot \Delta \wedge$ & فرض اسفيرسيتى & \multirow{4}{*}{ 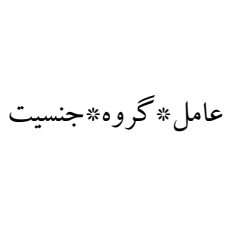 } \\
\hline$\cdots /$ & $\cdot / 9 \wedge r$ & $\cdot / . \cdot 4$ & $\cdot \% \mu_{\Lambda}$ & $1 /\left.\Delta\right|_{1}$ & $\cdot / \cdot \Delta \Lambda$ & گرينهاوس گيسر & \\
\hline$\cdots /$ & $\cdot / 9 \wedge 9$ & $\cdot / . \cdot 4$ & .1 .49 & $1 / 911$ & $\cdot / \cdot \Delta \wedge$ & هيون-فلت & \\
\hline$\cdots /$ & - /af. & $\cdot 1.04$ & $\cdot 1 \cdot \Delta \Lambda$ & $1 / \cdots$ &.$/ . \Delta \wedge$ & حد بايين & \\
\hline & & & $\Delta / 1 \cdot F$ & $10 \mathrm{r}$ & WD/ArT & فرض اسفيرسيتى & \multirow{4}{*}{ خطا } \\
\hline & & & $9 / 999$ & $119 / \pi 49$ & WD/ArT & گرينهاوس گيسر & \\
\hline & & & $9 / \pi 11$ & Irr/ard & WD/ArT & هيون-فلت & \\
\hline & & & $1 \cdot / r \cdot 1$ & $v 9 / \ldots$ & WD/Arr & حد هايين & \\
\hline
\end{tabular}

ايكوى بسر ان و دختران اقدام كننده به خود كشى در استان

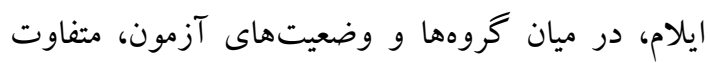

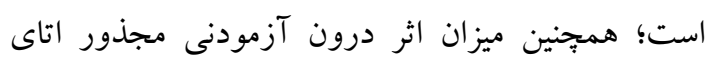

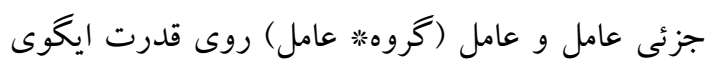

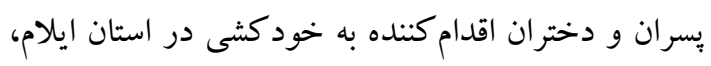

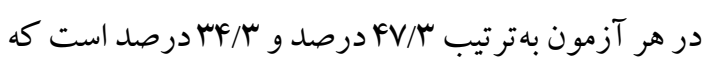

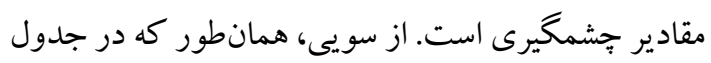

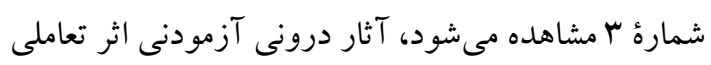

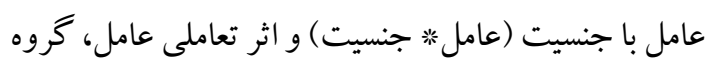

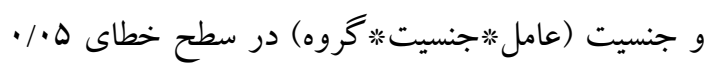

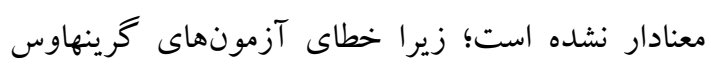

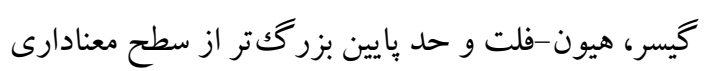

اقدام كننده به خودكشى در استان ايلام تأثير كذار نيست.

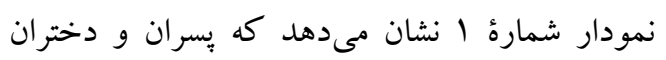

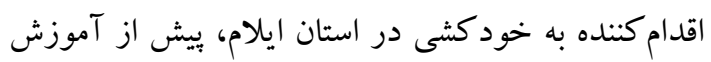

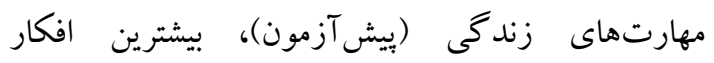

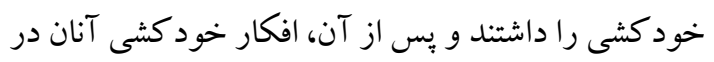
مرحلة بِ آزمون و ييخيرى كاهش مى يابد.همانطور كه

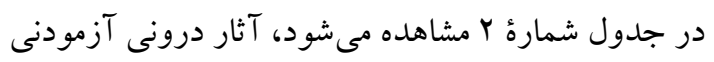
عامل و تعاملى عامل با گروه (عامل گتروه) متغير قدرت

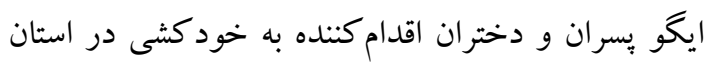
ايلام، در هر سه آزمون گرينهاوس گيسر، هيون-فلت و حد

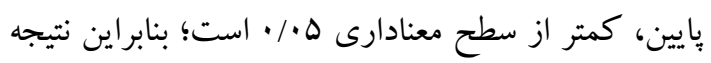

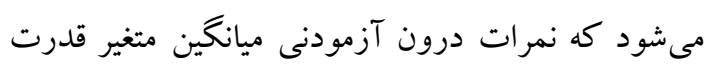


جدول r. نتايج آثار درون آزمودنى حاصل از تحليل واريانس با اندازهگيرى مكرر روى ميانگين قدرت ايخوى بسران و دختران اقدامكنده به خود كشى در استان ايلام

\begin{tabular}{|c|c|c|c|c|c|c|c|}
\hline تفاوت ميان & معنادارى سطح & خطاى & خانغاى & درادهُ & اندازهكيرى & آزمون & اثر \\
\hline$\varepsilon V / \mu$ & $<\cdot / \cdot \cdot 1$ & $T / T \cdot T$ & $097 / 2 r 9$ & r & $119 r / 101$ & فرض اسفيرسيتى & \multirow{4}{*}{ كامل } \\
\hline$\varepsilon \vee /$ & $<\cdot / \cdot \cdot 1$ & $T / T \cdot T$ & $1 \cdot 1 r / v 90$ & $1 / 1 \cdot r$ & $1194 / 101$ & گر ينهاوس گيسر & \\
\hline$\varepsilon V / \mu$ & $<\cdot / \cdot \cdot 1$ & $T / T \cdot T$ & $1 \cdot r V / T \wedge \varepsilon$ & $1 / 10$. & $1194 / 101$ & هيون-فلت & \\
\hline$\varepsilon \vee /$ & $<\cdot / \cdot \cdot l$ & $T / Y \cdot T$ & $119 \mathrm{r} / \mathrm{NON}$ & $1 / \cdots$ & $1194 / 101$ & حد بايين & \\
\hline$r \varepsilon / \mu$ & $<\cdot / \cdot \cdot 1$ & $r q / 7) \varepsilon$ & $r \varepsilon \tau / \varepsilon \cdot \varepsilon$ & r & $79 r / \Lambda \cdot 1$ & فرض اسفيرسيتى & \multirow{4}{*}{ عامل } \\
\hline$r \varepsilon / \mu$ & $<\cdot / \cdot \cdot 1$ & $r q / 71 \varepsilon$ & TYN/ANE & $1 / 1 \cdot r$ & $79 r / \Lambda \cdot 1$ & كرينهاوس گيسر & \\
\hline$r \varepsilon / \mu$ & $<\cdot / \cdot \cdot 1$ & $r q / 7) \varepsilon$ & $7 \cdot T / 201$ & $1 / 10$. & $79 r / 1 \cdot 1$ & هيون-فلت & \\
\hline$r \varepsilon / \mu$ & $<\cdot / \cdot \cdot l$ & $r q / 7) \varepsilon$ & $79 r / \Lambda \cdot 1$ & $1 / \cdots$ & $79 Y / \Lambda \cdot 1$ & حد بايين & \\
\hline$\cdot / 1$ & . $/ 9 T T$ & $\cdot / \cdot \wedge 1$ & . MIT & r & $1 / \varepsilon$ TO & فرض اسفيرسيتى & \multirow{8}{*}{ عامل *جنسيت } \\
\hline$\cdot / 1$ & $\cdot / \wedge \cdots$ & $\cdot / \cdot \wedge 1$ & $1 / T 9 \varepsilon$ & $1 / 1 \cdot r$ & 1/ETO & خرينهاوس گيسر & \\
\hline$\cdot / 1$ & $\cdot / 111$ & $\cdot / \cdot \wedge 1$ & $1 / T r q$ & $1 / 10$ & $1 / \varepsilon$ Yo & هيون-فلت & \\
\hline$\cdot / 1$ & $\cdot / \mathrm{VV} T$ & $\cdot / \cdot \wedge 1$ & 1/2YO & $1 / \cdots$ & 1/ZTO & حد يايين & \\
\hline$\cdot / 1$ &.$/ 9 \varepsilon$. &.$/ \cdot 71$ & . /OrV & r & $1 / \cdot$ Vo & فرض اسفيرسيتى & \\
\hline$\cdot / 1$ & $\cdot / A Y \Lambda$ & $\cdot / \cdot 71$ &.$/ 9 \vee 7$ & $1 / 1 \cdot r$ & $1 / \cdot$ Vo & كرينهاوس گيسر & \\
\hline$\cdot / 1$ & $\cdot / \Lambda \mu \Lambda$ &.$/ \cdot 71$ &.$/ 940$ & $1 / 10$. & $1 / \cdot v_{0}$ & هيون-فلت & \\
\hline \multirow[t]{5}{*}{$\cdot / 1$} & $\cdot / A \cdot 0$ & $\cdot / \cdot 71$ & $1 / \cdot 10$ & $1 / \cdots$ & $1 / \cdot v_{0}$ & حد پايين & \\
\hline & & & $\Lambda / V \varepsilon O$ & lor & $1 T r q / 17 V$ & فرض اسفير سيتى & \multirow{4}{*}{ خطا } \\
\hline & & & 10/AVo & AT/VTO & Irrg/I TV & خرينهاوس گيسر & \\
\hline & & & $10 / \pi \cdot 1$ & $\Lambda V / r q 9$ & IrYq/ITV & هيون-فلت & \\
\hline & & & $\mid V / \varepsilon \wedge q$ & $v \vee / \cdots$ & $1 T r q / 17 V$ & حد يايين & \\
\hline
\end{tabular}

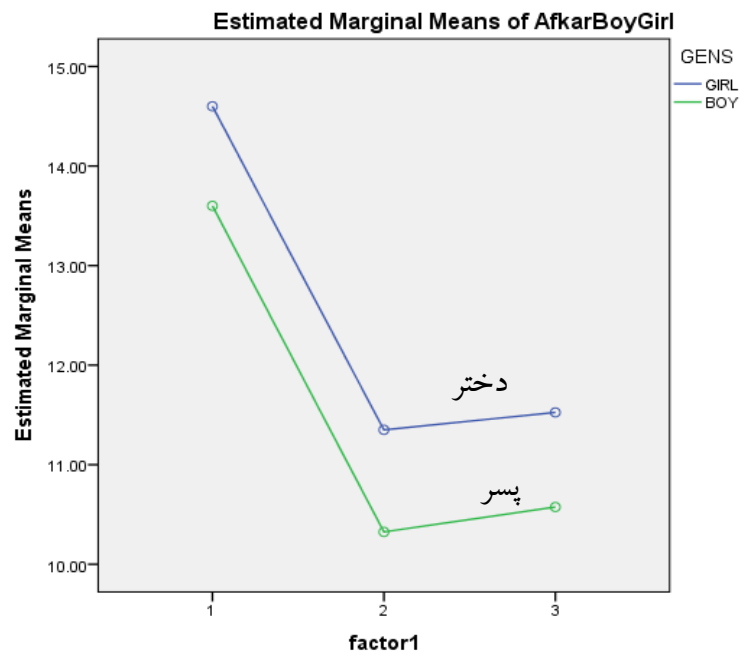

نمودار ا. ميزان افكار خود كشى اقدام كننده به خود كشى در استان ايلام در وضعيتهاى آزمون در ميان بِران و دختران 
جدول Гا. نتايج آثار درون آزمودنى حاصل از تحليل واريانس با اندازهيرى مكرر روى ميانكين خلقوخو در بسران و دختران اقدام كنده به خودكشى در استان ايلام

\begin{tabular}{|c|c|c|c|c|c|c|c|}
\hline تفاوت ميان & معنادارى سطح & خطاى & خطانكين & آزادى & اندازهكيرى & اثر & \\
\hline$g V / V$ & $<\cdot / \cdot \cdot 1$ & $109 / 19 \Delta$ & $1111 / 991$ & r & (THETKR & عامل & \\
\hline$v \cdot / \Lambda$ & $<\cdot / . \cdot 1$ & $\mid \Lambda F / 9 \Delta V$ & $1 r v \cdot / 9 T g$ & r & TVEI/AD & عامل *3روه & $\frac{1}{13}$ \\
\hline$F / V$ & $<\cdot / . \cdot 1$ & $r / V V r$ & $\langle N / \cdot \cdot \Lambda$ & r & $\Delta 9 / \cdot 19$ & عامل قجنسيت & í \\
\hline $1 \cdot / 4$ & $<\cdot|\cdot \cdot|$ & N/VAT & $Q \Delta / T \cdot T$ & r & $1 r \cdot / 4 \cdot 4$ & عامل * كروه* جنسيت & \\
\hline
\end{tabular}

سطح معنادارى هـ/• است؛ بنابراين نتيجه مىشود كه آموزش مهارتهاى زندگى سبب تفاوت نمرات ميان گروهن،

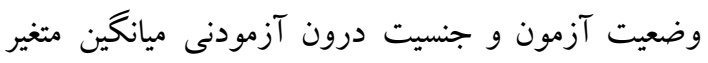

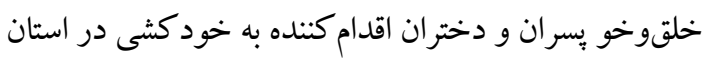

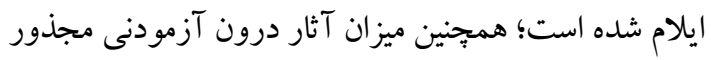

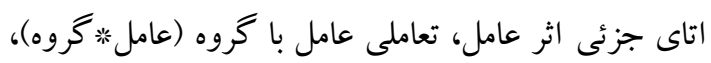

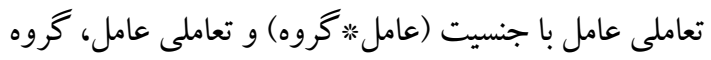

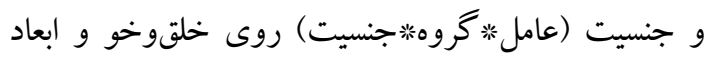

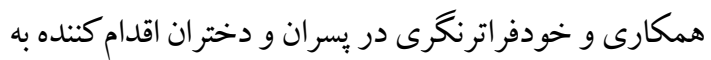

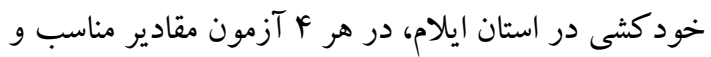
قابلتوجهى هستند؛ بنابراين نتيجه مىشود كه نمرات مئ ميان

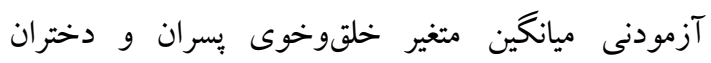
اقدامكننده به خودكشى در استان ايلام، در ميان جنسيت، متفاوت نيست؛ به عبارتى، عامل جنسيت در اثربخشى مهارتهاى زندگى بر خلقوخوى دختران و پيسران

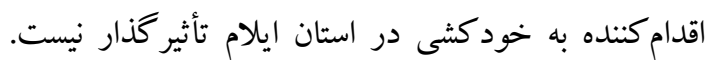

ه•• است؛ بنابراين نتيجه مىشود كه نمرات درون

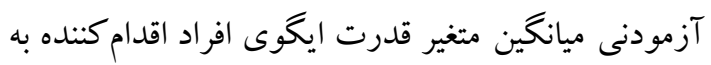
خودكشى در استان ايلام، برحسب جنسيت آنان، متفاوت

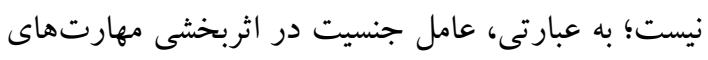

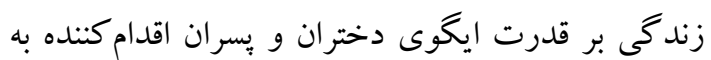
خود كشى در استان ايلام تأثير كذار نيست.

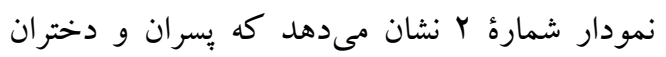

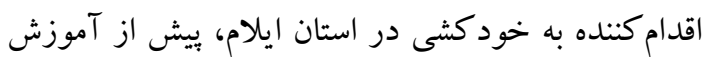

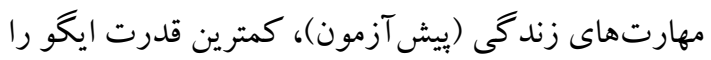

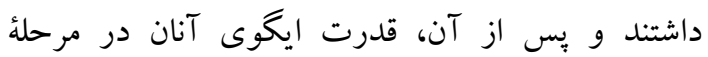
بس آزمون و ييخيرى افزايش مى ايابد. همانطور كه در جدول شمارة ب مشاهده مى شودود، آثار درونى آزمودنى عامل، تعاملى عامل با گروه (عامل **گروه)،

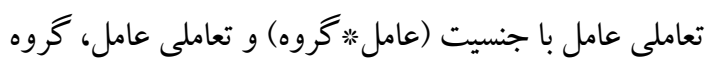

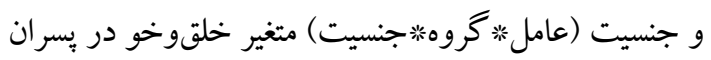

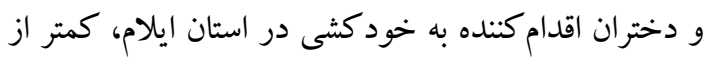

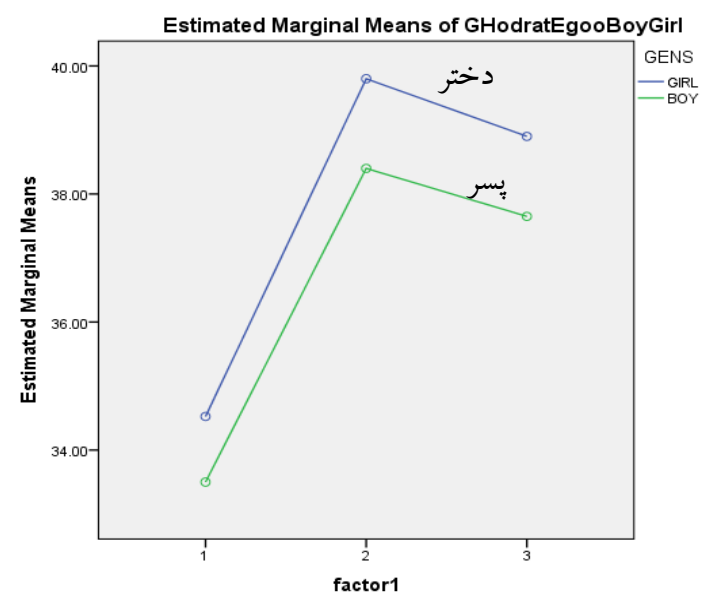

نمودار r. ميزان قدرت ايكوى اقدام كنده به خود كشى در استان ايلام در وضعيتهاى آزمون در ميان بسران و دختران 


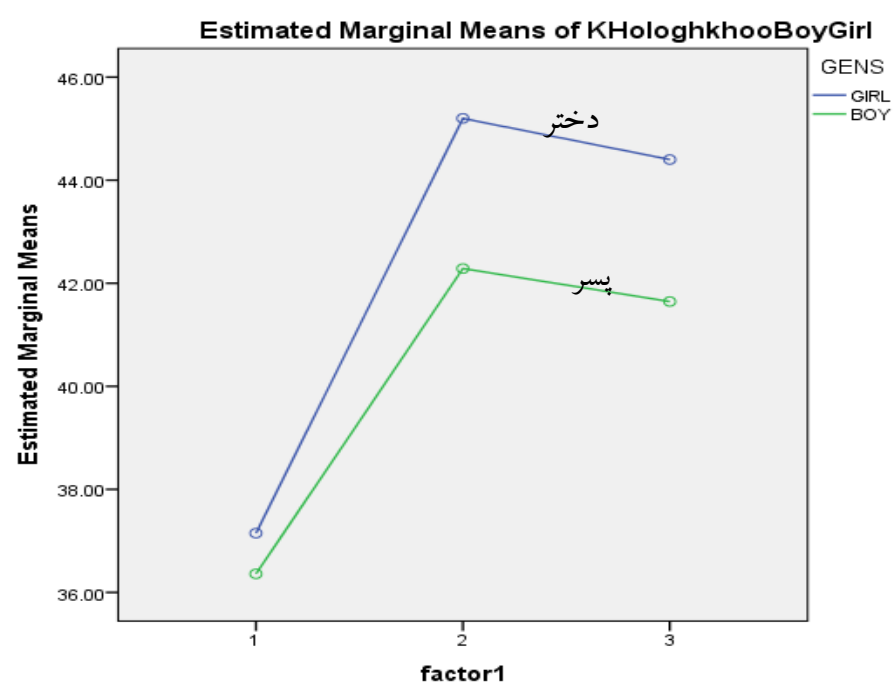

نمودار rا. ميزان خلقوخوى دختران و پِران اقدامكنده به خودكشى در استان ايلام در وضعيتهاى آزمون

افكار خود كشى در فرد كاهش مى يابد و اميد به زندگى در او افزوده مىشود . يادگيرى موفقيت آميز مهارتهاى

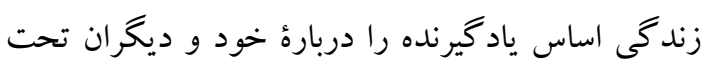

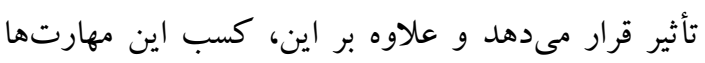

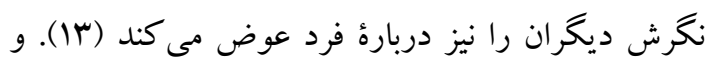

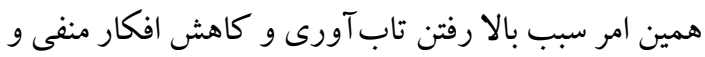

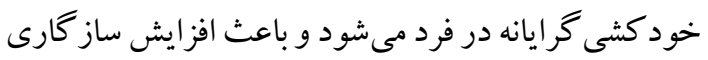

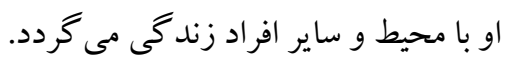

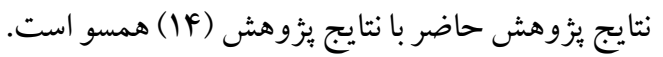

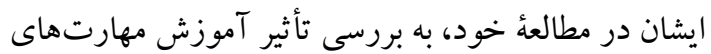
مقابله با استرس و افسردگى براى بيشخيرى از خود كشى

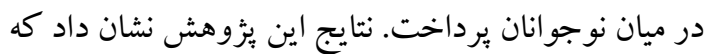
آموزش مهارتهاى مقابلهاى براى استرس، در افزايش كنترل خود و كاهش شدت افسردىى بسيار مؤثر است. نتايج ئزوهش (9) نيز نشان داد كه نوجوانانى كه اقدام به خود كشى كردهاند، بهصورت قابلملاحظهاى نمرة پايينى را در خود تاب آورى در مقايسه با نوجو انانى بهدست

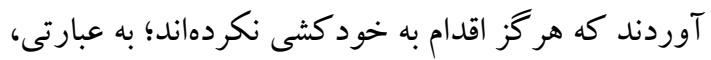

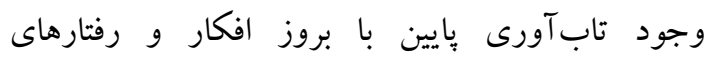
خود كشى گر ايانه ارتباط دارد.

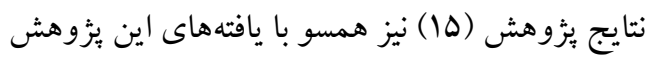

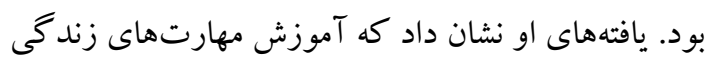

نمودار شماره r نشان مىدهد كه در گروه آزمايش

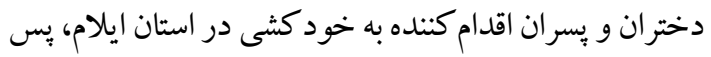

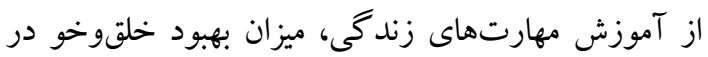
يس آزمون و ييخيرى افزايش مى ميابد.

\section{بحث و نتيجه كيرى}

از يافتهاى بهدست آمده جنين مئه توان استنباط كرد

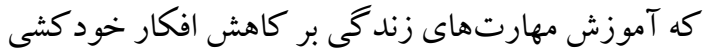
دختران و پِسران، هم در مرحلة بس آزمون و هم در مرحلة

$$
\text { ييخيرى، اثربخش بوده است. }
$$

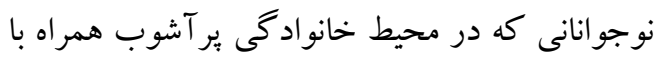
بى توجهى والدين نسبت به گروههاى ارتباطى فرزندان و

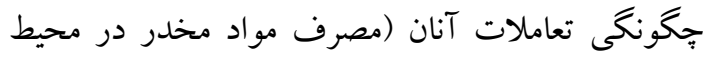
خانوادگىى، دسترسى به منابع نامناسب اينترنت، فيلمهاى

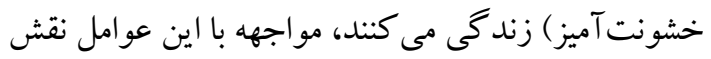
بسيار مهمى در يرورش افكار خودكشى آنان دارد.

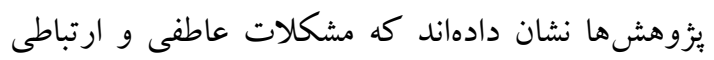
نقش بسيار مهمى را در اقدام به خود كشى نوجو انان ايفا دهان

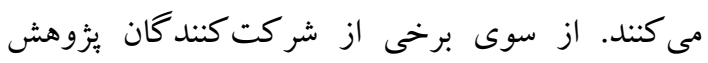

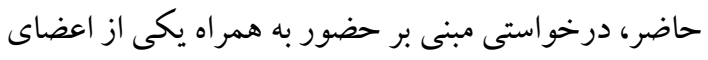

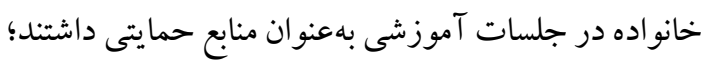
بنابراين، هرجه حمايت خانو اده از فرد بالاتر مىرود، ميزان 
جالشهاى ضرورى زندگى و درنهايت، تقويت قدرت

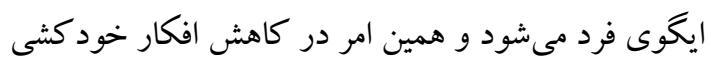
و افزايش اميد به زندگى افراد مؤثر است.

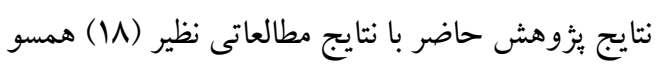
است كه در يروهشى، برنامة آموزش تقويت مهارتهاى زندگى زونى را در ميان نوجوانان اجرا و ارزيابى كردند.

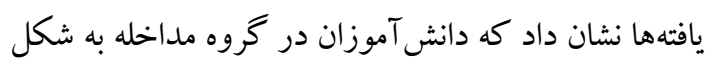
معنادارى، كاهش افكار خود كشى، احساس ناميدى كمتر را ״س از شركت در برنامه گزارش كردند و علاوه بر اين، كروه مداخله در يكك ارزيابى رفتارى نشان داد كه توانايى درئ بيشترى براى انجام مهارتهاى حل مسئله و مداخله دربارئ خود كشى دارند. (19) نيز به بررسى اثربخشى مهارتهاى

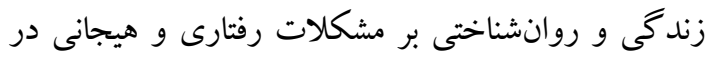

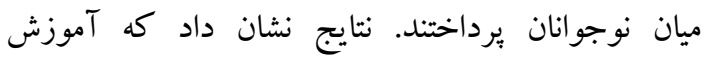
مهارتهاى زندگى و روانشناختى به كاهش مشكلات

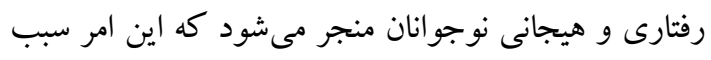

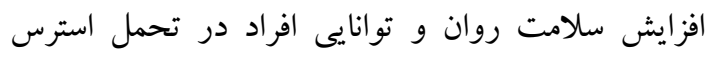

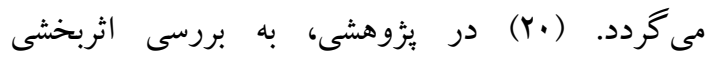
درمانشناختى بر قدرت ايخو و روابط موضوعى افراد مبتلا به اختلال شخصيت مرزى يرداختند. نتايج نشان داد كه

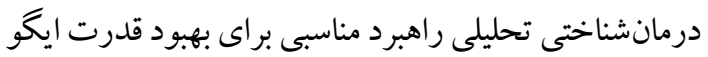

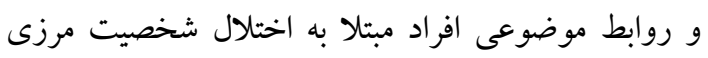
است و مى توان از آن بهعنوان يكك شيوهُ مؤثر استفاده كرد.

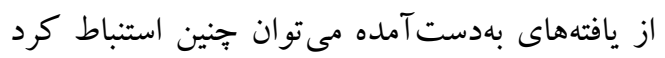

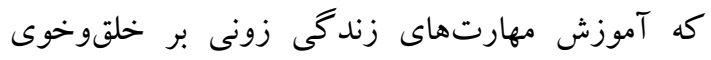

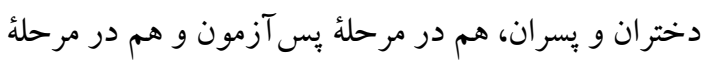
بيخيرى، اثربخش بوده است.

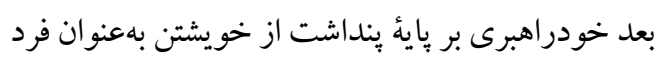
مستقل استوار است و احساساتى نظير وحدت، احترام، عزتنفس، كار آمدى، رهبرى و اميدوارى از اين خودانكاره

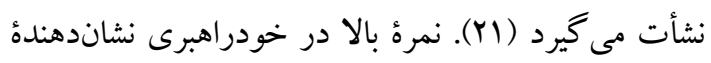

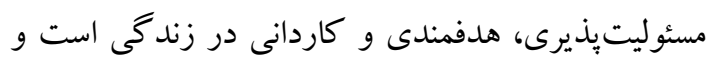

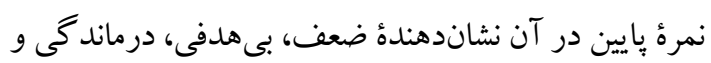
بى مسئوليتى است. نمرةٔ بالا در بعد همكارى شخصيت
در افزايش معنادار ساز كارى اجتماعى و بيشگيرى از افكار خو دكشى دختران مهاجر گروه آزمايش در مقايسه با كروه كنترل مؤثر است. از يافتههاى بهدست آمده جنين مى توان استبن استباط كرد

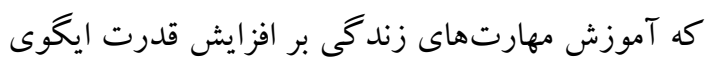

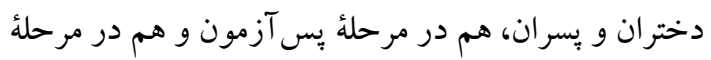
يّيخيرى، اثربخش بوده است.

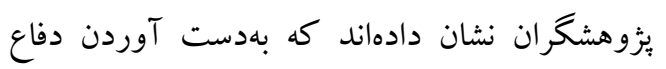
جديد و سازو كارهاى رويارويى مؤلفهُ مهمى از قدرت

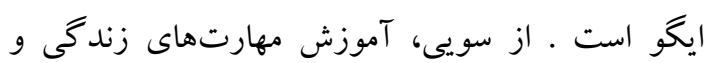
تقويت عوامل محافظتى نظير عزتنفس، ارائه مهارتهاى إنى عمومى و توانمندىهاى اجتماعى مانند حل مسئله است كه

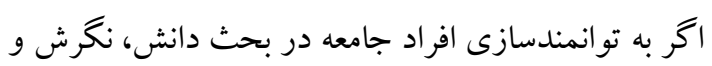
مهارت بهصورت تلفيقى توجه نشود، نتيجة مورد انتظار يعنى كاهش رفتارهاى برخطر بهدست نمى آيد (19).

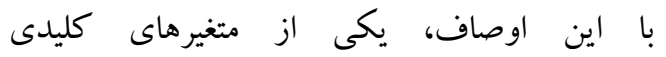

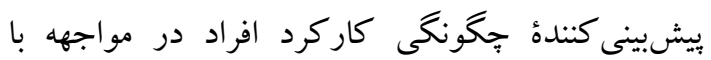
استر سورهاى محيطى و درنتيجه خود كشى، سطوح قدرت ايخو است؛ بنابراين مىتوان بيان كرد كه فردى با قدرت

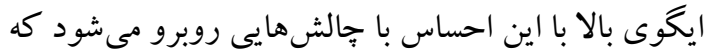

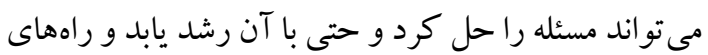
جديدى براى حل اختلافات بيابد. قدرت ايكوى بالا بالا در

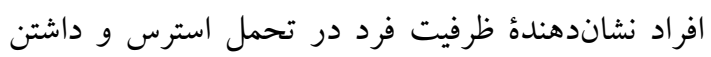
احساس صلاحيت و خودبسندگى در حوزه شخصى و

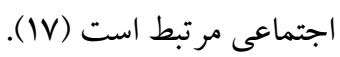
افزايش قدرت ايكو و توانايى تحمل استرس و حل حل

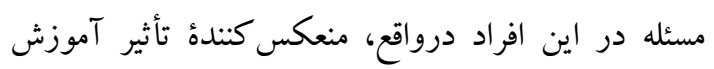

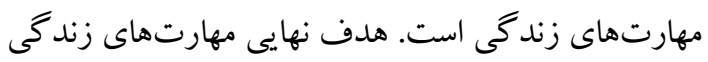

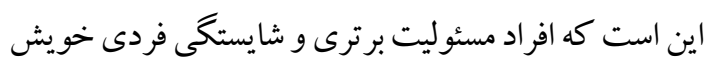

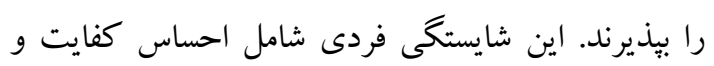

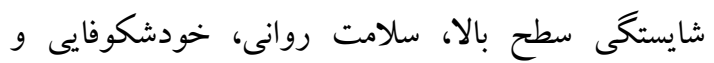

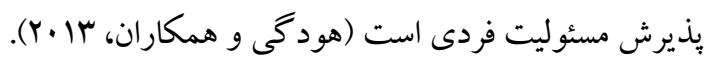

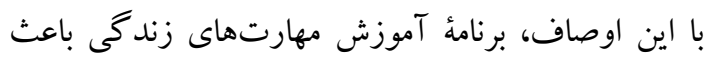

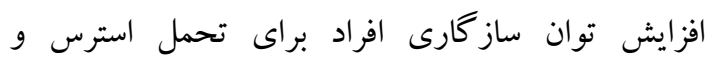


يُزوهشها نشان دادهاند كه خودكشى از نظر زنتيكى، در

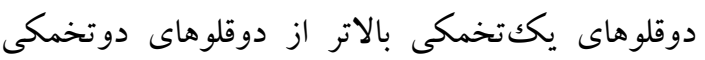

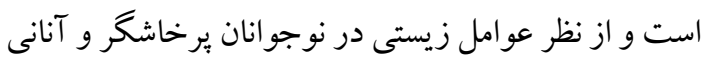

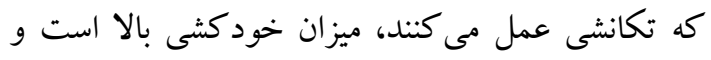

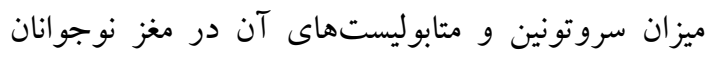

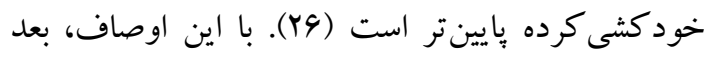

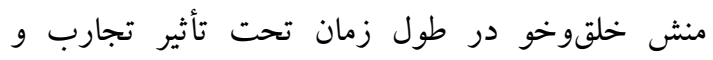

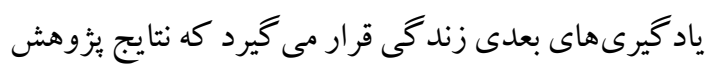

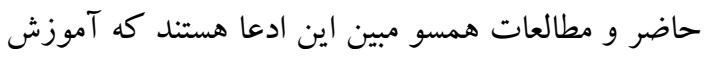
مهارتهاى زندگى باعث افزايش توانمندى فردى مئ،

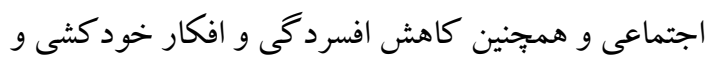

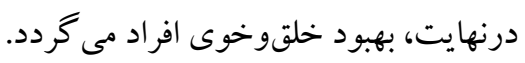
محدوديتها: هماند هر يزوهشى، يزوهش حاضر نيز محدوديتهايى داشت كه توجه به آنها، راه را براى

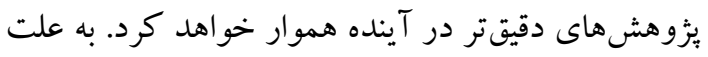
محدوديتهاى زمانى يزوهش، ارزيابى اثربخشى برنامة

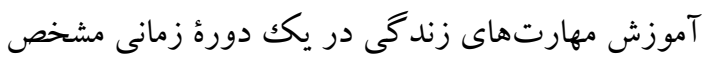
صورت گرفت. جنانجه امكان بيخيرى وضعيت مراجعان در مدتى طولانىتر از سه ماه فراهم بود، احتمالاً نتايج

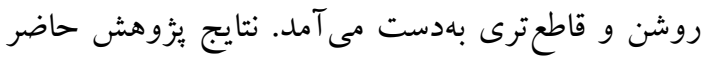

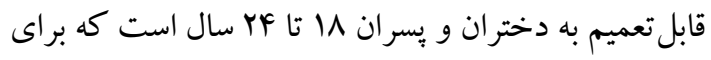
بار اول اقدام به خود كشى و به مراكز درمانى دانشكاه علوم يزشكى استان ايلام مراجعه كردهاند. در صورت بود نياز به به دمانه

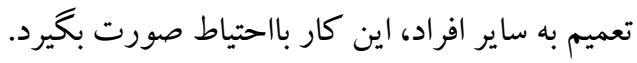

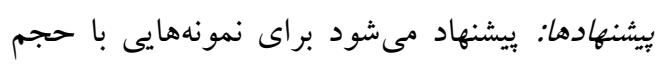

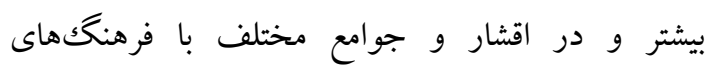

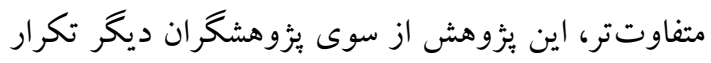

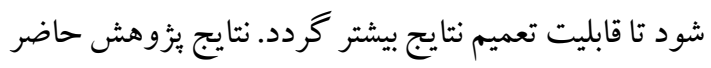

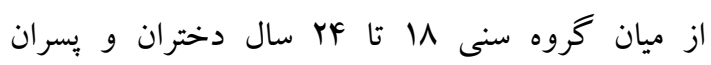

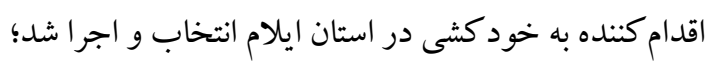

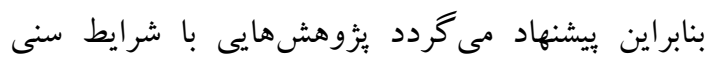

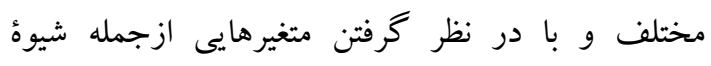
خود كشى، هوش افراد، وضعيت اقتصادى، اشتغال و... نيز

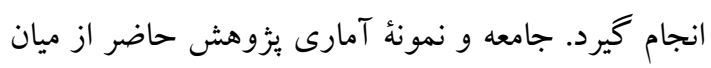

نشاندهندة تحمل بسيار و توانايى بالا است و نمرة بايين

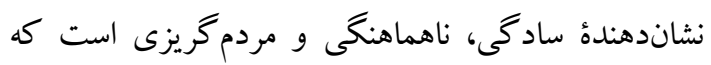

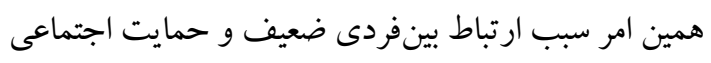

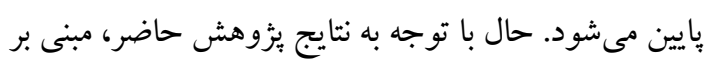

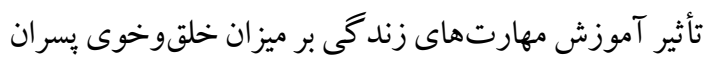

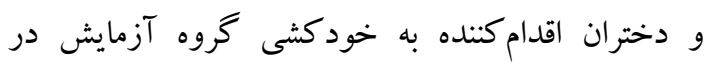

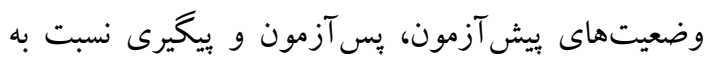

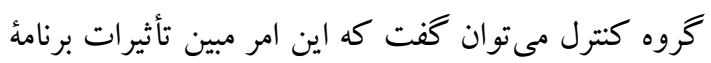

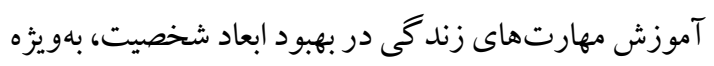
بعد خودراهبرى و همكارى است.

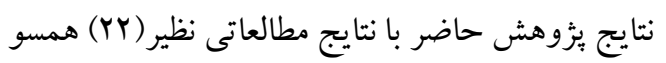

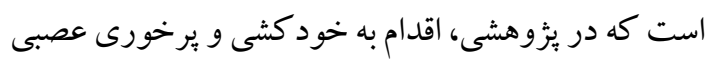

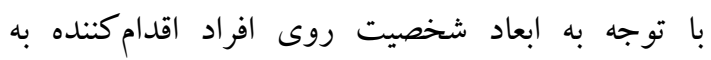

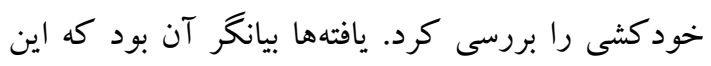

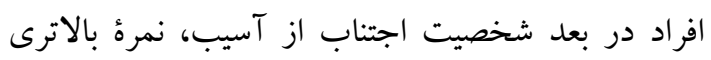

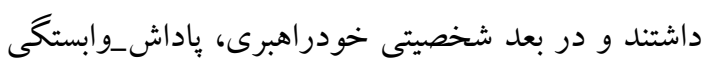

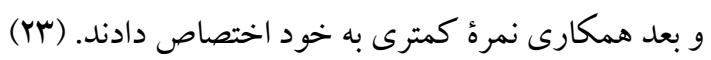
يزوهشى را بهمنظور بررسى خلقوخو و شخصيت افراد و نقش آن در اقدام به خودكشى انجام داد و نتايج آن بيان كرد كه افراد اقدام كننده به خود كشى در اجتناب از آسيب، نمرة بالاتر و در خودراهبرى و همكارى نمرهُ بايينترى

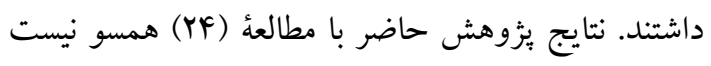
كه در يزوهشى، به بررسى نقش زنها و صفات شخصيتى

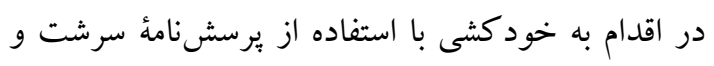

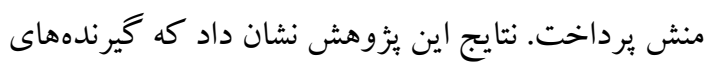

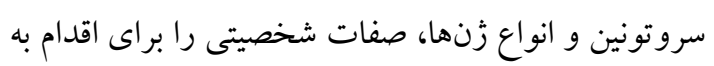
خو دكشى يشتيبانى نمى كند. اين يافتهها درواقع بيانكر تأثير

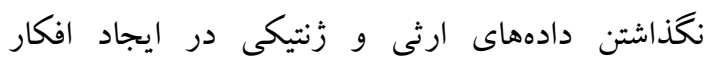

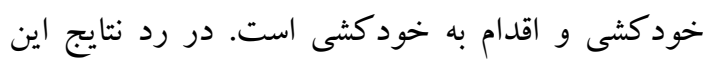

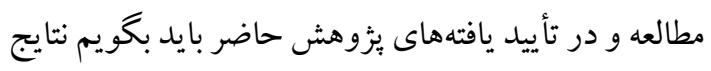

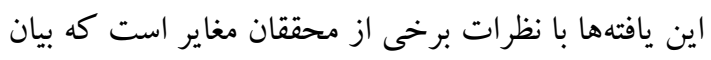
مى دارند ويز گىهاى شخصيت به علت اينكه نسبتاً بايدار

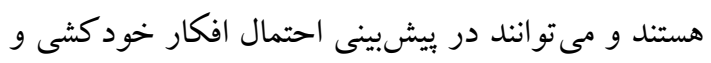

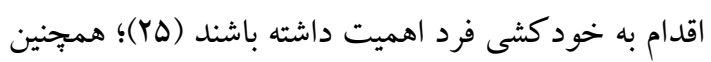




$$
\begin{aligned}
& \text { بهمنظور انجام اقدامات بيشخيرانه براى افراد در معرض } \\
& \text { آسيب هاى اجتماعى تعيين شود. }
\end{aligned}
$$$$
\text { تشكر و قدردانى }
$$

\section{تعارض منافع}

نويسند كان اعلام مى كنند كه تضاد منافعى در اين

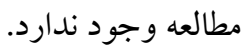

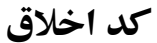

$$
\begin{aligned}
& \text { تمام ملاحظات اخلاقى بر اسـاس كد يايان نامه شـماره }
\end{aligned}
$$

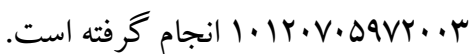

\section{References}

1. Alipordinia A, Yousefi N. Explaining the ideation of suicide from the perspective of public pressure theory. Soc Dev Quarter2015; 10: 157-86.

2. Kurdish R, Kazemi M, Hosseini SA, Assyrian Y. A look at the phenomenon of suicide in Iran. Dep Min SocWelf2014; 2:1-100.

3. Bahamin GH, Panaghi L. Investigation and determination of the main factors leading to suicide in Ilam city. Sui Assess Manage Uni Tehran2014; 5:43-8.

4. Mohammadkhani P. Epidemiology of suicidal ideation and suicide attempt in girls in high risk areas of Iran. Soc Welf Quarter 2004; 14: 144-62.

5. Babanejad M, Pourkarmakhan T, delpisheh A, Khorshidi Ali, Asadullahi Kh, Shadow C. [Epidemiological study of suicide due to mental disorders in Ilam province during 1993-2009]. J Ilam Uni Med Sci2013; 22: 104-13. (Persian)

6. Altunayoglucakmak V, Gazioglu S, Canusta N, Ozkorumak E, Ayar A, Topbas M, et al. Evaluation of temperament and character features as risk factors for depressive symptoms in patients with restless legs syndrome. J Clini Neurol2014; 10: 320-7. doi.10.3988/jcn.2014.10.4.320

7. Sivandian M, Besharat MA, Asgarabad MH,
همدٔ افرادى است كه براى بار اول اقدام به خود كشى و به مر اكز درمانى دانشخاه علوم يزشكى ايلام مر اجعه كردهاند؛ بنابراين بيشنهاد مىشود نمونههايى از افرادى كه به ساير مر اكز درمانى نظير كلينيك ها، مر اكز يزشكى قانونى، مطب روانيزشكان مراجعه داشتهاند، بهعنوان جامعه و نمونهُ آمارى انتخاب كردد و نتايج بهدست آمده با يافتههاى بزوهش حاضر مقايسه شود.

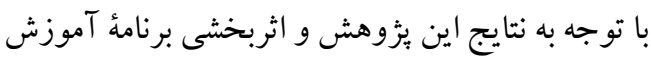

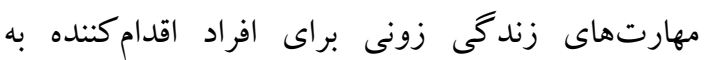
خودكشى لازم است كارگاه برنامة توسعة آموزش برى مهارتهاى زندكى زونى در مراكز درمانى دانشگاههاى علوم يزشكى و سازمان بهزيستى در سراسر كشور براى افراد اقدامكننده به خودكشى و ساير افراد داراى افكار خود كشى بركزار گردد.

با توجه به درخواست برخى از شركت كنتد كان مبنى

بر شركت در جلسات آموزشى به همراه يكى از اعضاى به به لهر خانواده بهعنوان منابع حمايتى، بيشنهاد مىشود كه در اجراى يزوهشهاى آتى و برنامههاى آموزشى، از روش و

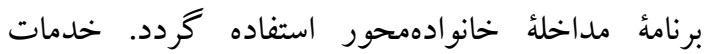
روانشناختى و برنامه آموزش بهورزان خانهاى بهداشت،

Moghadamzade A. The moderating role of ego strength on the relationship between attachment styles and marital adjustment. Salam Ijtim J 2016; 3: 41-53. doi.10.22038/MJMS.2019.13910

8. Panaghi L. Suicide assessment and management. $1^{\text {th }}$ ed. Uni Tehran Publication. 2011; P.23-97.

9. Askari S. Resilience and suicidal motivations. Thesis Facul Psychol Allameh Uni2017;1-50

10. Khadivi R, Moezzi M, Shakeri M, Borjian MT. [The effect of life skills training in suicide prevention in women of Ardabil city]. Sci J Ilam Uni Med Sci2005; 13: 13-20. (Persian)

11. Aliakbari M, Shaghaghi F, Kokajoybari AA, Zare M, Shayeghian Z. A study of psychometric properties in the mood questionnaire. Edu Measure Quarter2012; 8:73-8.

12. Cloninger CR, Svrakic DM, Przybeck TR. A psychobiological model of temperament and character. Arch Gen Psychiatr1994;50: 975-90

13. Steptoe A, Wardle J. Life skills wealth health and wellbeing in later life. Proce Na Acad Sci2017; 114: 4354-9. doi.10.1073/pnas.1616011114

14. Adiana keleit. The influence of the training of stress on self control and intensity of depression among adolescrnts with suicide risks. Int $\mathrm{J}$ Adv Nurs 
Stud2019; 3:123-8. doi.10.14419/ijans.v4i2.4928

15. Nosrati N. The effectiveness of life skills training on increasing social adjustment and preventing suicidal ideation of migrant girls. Msc Thesis Clin Psychol Ferdowsi Uni Mashhad2015;12-32.

16. Velz R, Singh B. General population strategies of suicide prevention. Int Hand Sui Att Sui2019;3: 597-615. doi.10.1192/bjp.bp.107.040550

17. Sharma BN. Youth suicide. First Sui Att2012; 2:32-7. doi.10.1016/j.jaac.2018.05.022

18. Romano J. Preventive psychology. $1^{\text {th }}$ ed. Ministr Sci Res Technol Publications.2015; P.212-34.

19. Mutiso V, Tele A, Musyimi C, Gitonga I, Musau A, Ndetei D. Effectiveness of life skills education and psychoeducation on emotional and behavioral problems among adolescents in institutional care in Kenya a longitudinal study. Child Adolescent Mental Health2017; 3:71-6. doi. $0.1111 /$ camh. 12232

20. Eini S, Nariman M, Atadokht A, Basharpour S, Sadeghi F. [The effectiveness of cognitive therapy on ego power and thematic relationships in people with borderline personality disorder]. J Sci Urmia Medicine2018; 29: 11- 1. (Persian)

21. Jylha PJ, Rosenstrom T, Mantere O, Suominen K, Melartin TK, Vuorilehto MSet al. Temperament character and suicide attempts in unipolar and bipolar mood disorders. J Clin Psychiatr2016; 77: 252-60. doi. 10.4088/JCP.14m09472

22. Forkano K. The zuni life skills development program a school community based suicide prevention intervention. Sui life Threat Behavior2007; 38:34353. doi. 10.1521/suli.2008.38.3.343

23. Salati R. Suicidal behaviour and its meaning in adolescence. In Facing It Out2007; 2: 65-78. doi.10.1007/s40894-017-0066-Z

24. Serretti, A. Temperament and character of suicide attempters. J psychiatr Res2008;42: 938-45. doi.10.1016/j.jpsychires.2007.10.006

25. Paris J. Personality disorders and suicidality. Int Hand Sui Preve2016;124-32. doi.10.1177/ 136346159102800102

26. Azar M, Nohi S. Suicide. 3 th ed. Arjmand Publications. 2015; P.111-45. 